Scientific Journal of October 6 University

ISSN (Print): 2314-8640

ISSN (Electronic): 2356-8119

Published by October 6 University @ All Rights Reserved

Available online at: http://sjou.journals.ekb.eg
Citation: Shawky, (2018). Biochemical effects of some trace elements in experimental diabetic rats. Sci. J. of Oct. 6 Univ. 4(2), 14-22.

Copyright: () 2018 Shawky S. This is an open-access article distributed under the terms of the Creative Commons Attribution License, which permits unrestricted use, distribution, and reproduction in any medium, provided the original author and source are credited.

Original Article

\title{
Biochemical Effects of Some Trace Elements in Experimental Diabetic Rats
}

\author{
Suzan Shawky ${ }^{1}$, Samy A. Abdel-Aziz ${ }^{2}$, Hassan A. Amer ${ }^{2}$, Ismail I. Hegazy ${ }^{1}$ and ${ }^{*}$ Mohammed A. \\ Hussein ${ }^{1}$
}

${ }^{1}$ Department of Biochemistry, Faculty of Applied Medical Sciences, October 6 University, Egypt

${ }^{2}$ Department of Biochemistry and Nutrition, Faculty of Veterinary Medicine, Cairo University, Egypt

Received: 05-05-2018/ Revised: 13-06-2018 / Accepted: 10-08-2018

\begin{abstract}
The present work was done to elucidate the possible protective and antioxidant effect of chromium (Cr) as chromium chloride $\left(\mathrm{CrCl}_{2} ; 500 \mathrm{mg} / \mathrm{k}\right.$.g.), selenium (Se) as sodium selenite $\left(\mathrm{Na}_{2} \mathrm{SeO}_{3} ; 1.5 \mathrm{mg} / \mathrm{k} . \mathrm{g}\right.$.) and zinc $(\mathrm{Zn})$ as zinc sulphate $\left(\mathrm{ZnSO}_{4} ; 54 \mathrm{mg} / \mathrm{k}\right.$.g.) supplementation in streptozotocin induced diabetic rats. Administration of these elements daily for 60 days showed a significant decrease in MDA concentrations. The treatment resulted also in a significant increase in plasma insulin C-peptide, blood reduced glutathione (GSH) levels and superoxide dismutase (SOD)activity as well as gene expression of heart glucose transporter 4 (GLUT4) of diabetic rats. Also, the results clearly suggested that the trace elements can normalize effectively the body weight as well as high density lipoprotein (HDL-C) in streptozotocin diabetic rats. The trace elements reduced the risk of diabetic complications through rapid protective effects against lipid peroxidation by scavenging of free radicals there. These effects were more pronounced in $\mathrm{Cr}$ - treated group than $\mathrm{Se}$ and $\mathrm{Zn}$-treated groups.
\end{abstract}

Key words: Trace elements, diabetic rats, oxidative stress biomarkers, C-peptide.

\section{Introduction}

Diabetes mellitus is ranked seventh among the leading causes of death and is considered third when it's a total complications are taken into account (Trivedi et al., 2004). There is increasing evidence that complications related to diabetes are associated with oxidative stress induced by the generation of free radicals (Garg et al., 1996). Antioxidants were then subjected of extensive research as they protect cells against the damaging effects of reactive oxygen species (ROS), such as singlet oxygen, superoxide, peroxyl radicals, hydroxyl radicals and peroxynitrite. An imbalance between antioxidants and ROS results in an oxidative stress (OS) status, leading to cellular damage. Oxidative stress has been linked to cancer, ageing, atherosclerosis, ischemic injury, inflammation and neurodegenerative diseases (Olson and Seidel, 2000). Increased generation of reactive oxygen species (ROS) and lipid peroxidation has been found to be involved in the pathogenesis of many diseases of known and unknown etiology and in the toxic actions of many compounds (Andallu and Varadacharyulu, 2003). Thus antioxidants play an important role in protection of human body against damage caused by reactive oxygen species (Baynes, 1991). The endogenous antioxidant enzymes (e.g SOD, CAT, GR and GSHpx) are responsible for the detoxification of deleterious oxygen radicals (Jacob, 1995).

Some trace elements, particularly selenium (Se), zinc $(\mathrm{Zn})$ and chromium $(\mathrm{Cr})$ can support antioxidant function and consequently reduction in mortality in critically ill patients (Yanardag et al, 2005). Se, $\mathrm{Zn}$ and $\mathrm{Cr}$ are essential trace elements for all organisms, body growth and development (Jain and Kannan, 2001). They also play a role in supporting the immune system and affecting the integrity of the epithelial barrier and the function of white blood cells (O'Connell, 2001). The biologic role of $\mathrm{Se}, \mathrm{Zn}$ and $\mathrm{Cu}$ is now recognized in structure and function of proteins, including enzymes, transcription factors, hormonal receptor sites and biologic membranes (Kunwar and Priyadarsini, 2011). The trace elements act 
essentially as cofactors for antioxidant enzymes involved in the destruction of toxic free radicals produced in the body. The changes in the levels of trace elements can apply a pronounced influence in the immunity of organism and production of different cytokines (Nemati et al., 2012). The present investigation was undertaken to assess the protective effect of some trace elements $(\mathrm{Cr}, \mathrm{Se}$ and $\mathrm{Zn}$ ) against streptozotocin (STZ) induced diabetes through investigation of changes in oxidative stress biomarkers, insulin C-peptide, gene expression of heart GLUT-4 and lipid profile in rats.

\section{Materials and Methods}

Materials

Chromium chloride, sodium selenite, Zinc sulphate, glibenclamide and streptozotocin were purchased from Sigma Aldrich (St. Louis, MO), USA.

\section{Animals \\ A 225 Male albino rats (120-150 g) were obtained from animal house of Cancer Epidemiology, National Cancer Institute, Cairo University. Rats were fed on a standard diet and free access to tap water. They were kept for one week to be acclimatized to the environmental conditions.}

\section{Experimental Design}

A 225 male albino rats were divided into 2 main groups the $1^{\text {st }}$ group included the normal healthy rats comprised of 100 rats while the $2^{\text {nd }}$ group was experimentally induced diabetic group and comprised of 125 rats (twenty five rats in each group).

The $1^{\text {st }}$ group included the normal healthy rats were divided into 4 subgroups as follows:

Group 1: Given saline served as negative control. Group 2: Normal healthy control rats; orally administered with $\mathrm{Cr}(500 \mathrm{mg} / \mathrm{kg} \mathrm{BW})$ for 60 days (Zhongli, 2010).

Group 3: Normal healthy control rats; i.p injected with Se (1.5 mg/kg b.w.) as for 60 days (Zhongli, 2010).

Group 4: Normal healthy control rats; orally administered with $\mathrm{Zn}$ (54 mg zinc/kg. b.w.) for 60 days. daily (Zine et al,. 2007).

The $2^{\text {nd }}$ group was experimentally induced diabetic group and comprised of 125 rats.

diabetic group was experimentally induced by injection with streptozotocin (STZ) i.p. in dose of $(65 \mathrm{mg} / \mathrm{kg} \mathrm{b}$. wt). STZ was dissolved in $0.01 \mathrm{M}$ citrate buffer $(\mathrm{pH}=4.6)$ immediately before use (Liu et al. 2008). After injection, animals had free access to food and water and were given $5 \%$ glucose solution to drink overnight to encounter hyperglycemic shock. Animals were checked daily for the presence of glycosuria. Fasting blood samples were obtained after 7 days of STZ injection to ensure the induction of Hyperglycemic fasting blood sugar was determined (>300 mg/dl).
Diabetic rats were classified into 5 groups (25 rats for each group) as follows:

Groups 5: Considered as a positive control for diabetic rats.

Group 6: diabetic rats orally administered with the anti-diabetic drug glibenclamide $(5 \mathrm{mg} / \mathrm{kg}$ body weight daily for to month).

Group7: Diabetic rats; orally administered with $\mathrm{Cr}$ $(500 \mathrm{mg} / \mathrm{kg} \mathrm{BW})$ for 60 days.

Group 8: Diabetic animals; i.p. injected with $\mathrm{Se}$ $(1.5 \mathrm{mg} / \mathrm{kg}$ b.w) for 60 days .

Group 9: Diabetic animals; orally administered with Zn (54 mg zinc/ mg/kg b.w. daily for 60 days

- Changes of body weight (gm) of rats in different groups were measured at $4^{\text {nd }}$ and $8^{\text {th }}$ week.

\section{- Sampling:}

Blood samples were collected twice at the end of fourth and eighth weeks of experiment (the end of experiment). Heart and liver specimens were obtained after slaughtering of rats at the end of experiment. Blood samples were divided into 3 portions:-

$1^{\text {st }}$ portion was collected in heparinized tubes for estimation of GSH according to Chanarin, (1989) and SOD activity according to Marklund and

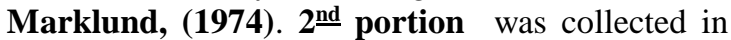
tubs containing sodium fluoride to assay blood glucose level according to the method of Trinder (1969). $3^{\text {rd }}$ portion was collected without anticoagulant for separation of serum for determination concentrations of trace elements (Lockitch, 1988), MDA according to the method of Uchiyama and Mihara, (1978), lipid profiles; TC, TG, HDL-C and LDL-C according to the methods of Allain et al.,(1974), Fossati and Prencipe,(1982), Warnick, et al (1985) and Friedwald et al., (1972), respectively. Also estimation of insulin C-peptide according to the method of Bonger, and Garcia-Webb, (1984). At the end of the experiment heart tissue was taken from for investigation of GLUT4 gene expression according the method of Abel et al., (2001) using total RNA isolation system (Promega, Madison, WI, USA) (Livak, J. K., and Schmittgen, 2001). The obtained data were analyzed statistically according to Levesque (2007).

\section{I- Results}

Tables (1) shows changes in serum MDA, blood reduced glutathione (GSH) levels and superoxide dismutase (SOD) activity in control and experimental groups of rats. In diabetic rats (group 5) serum MDA level increased, while blood reduced glutathione (GSH) and superoxide dismutase (SOD) activity were decreased significantly than normal group. Administration of glibenclamide and trace elements $\left(\mathrm{Zn}^{+2}, \mathrm{Se}^{+2}\right.$ and 
$\mathrm{Cr}^{+2}$ ) tends to bring MDA, GSH levels and superoxide dismutase (SOD) activity towards normal ranges $(\mathrm{P}<0.05)$ after 8 weeks.

Table (2) shows changes of fasting plasma glucose level, serum insulin C-peptide level and heart GLUT4 expression of control and experimental groups of rats. STZ caused a significant increase in plasma glucose level in diabetic control group as compared with normal control rats $(\mathrm{P} \leq 0.05)$. Administration of glibenclamide and trace elements $\left(\mathrm{Cr}^{+2}, \mathrm{Se}^{+2}\right.$ and $\mathrm{Zn}^{+2}$ ) tends to bring down the blood glucose level as compared with group (5) after 8 weeks. On the other hand, STZ caused significant decrease in both serum insulin Cpeptide levels and expression of heart GLUT4 in diabetic control group as compared with normal control rats $(\mathrm{P} \leq 0.05)$. Administration of both glibenclamide and trace elements increased significantly of plasma C-peptide levels as compared with untreated diabetic rats $(\mathrm{P} \leq 0.05)$. While administration of traces elements $\left(\mathrm{Se}^{+2}, \mathrm{Zn}^{+2}\right.$ and $\mathrm{Cr}^{+2}$ ) but not glibenclamide activated heart GLUT4 expression towards normal range after 8 weeks. Selenium increased significantly heart GLUT4 expression higher than normal rats in group (1).

Tables 3 and 4 show changes in lipid profile in diabetic and treated groups. STZ in group (5) increased significantly serum cholesterol, triacyglycerol, and LDL-C levels, and decreased HDL-C level than normal group. Administration of glibenclamide and trace elements $\left(\mathrm{Zn}^{+2}, \mathrm{Se}^{+2}\right.$ and $\mathrm{Cr}^{+2}$ ) decreased significantly serum cholesterol, triacyglycerol and LDL-C levels and increased HDL-C level than diabetic rats of group (5) after 8 weeks.

\section{II- Discussion}

The present study was conducted to evaluate the beneficial effects of trace elements $\left(\mathrm{Se}^{+2}, \mathrm{Cr}^{+2}\right.$ and $\mathrm{Zn}^{+2}$ ) on oxidative stress in STZ-induced diabetic rats. Data in table (1) stated that STZ diabetic rats exhibited an oxidative stress status manifested by significant increasing in serum MDA level and decreasing in blood GSH concentration as well as inhibition of blood SOD activity after 8 weeks. STZ stimulated the generation of ROS the intracellular molecules which increased lipid hydroperoxides characterized by an increased oxidative biomarkers (MDA). That caused an imbalance status between the generation of ROS and the endogenous antioxidant mechanisms and consequently the oxidative stress condition.

These results were consistent with that of Ramesh and Pugalendi (2005) who recorded an increase in lipid hydroperoxides and decrease of SOD activity in experimentally diabetic rats.

Coskun et al. (2005) reported that the oxidative stress is a result of a redox imbalance between the generation of ROS and the compensatory response from the endogenous antioxidant network as reduction in the activities of antioxidant enzymes as SOD in diabetic rats.

The decrease in antioxidant enzyme activity under diabetic conditions may be due to glycation of these enzymes, which occurred at persistently elevated blood glucose levels (Taniguchi, 1992). Glycation of SOD reduces its activity, leading to the insufficient dismutation of superoxide anions (Ravi et al. 2004 ; and Majithiya and Balaram 2005).

Merzouk et al. (2004), stated that elevated levels of hydroperoxide in the serum increased the generation of ROS in diabetes mellitus.

On the hand others, Sanders et al. (2001) and Yilmaz et al. (2004) recorded an increased SOD activity in streptozotocin-induced diabetic rats. That increase in SOD activity may be due to its induction by increased production of superoxide ion and $\mathrm{H}_{2} \mathrm{O}_{2}$ which act as an inducer of tissue SOD ( Dias et al. 2005).

Several studies have demonstrated the involvement of free radicals in the genesis of diabetes mellitus and their role in the induction of lipid peroxidation during diabetes. Tomlinson et al., (1992), suggested free radical involvement in pancreatic cell destruction. It has been reported that in diabetes mellitus, oxygen free radicals are generated by stimulating $\mathrm{H}_{2} \mathrm{O}_{2}$ in vitro as well as in vivo and in pancreatic $\beta$-cells (Ju, et al., 2008). The increased lipid peroxidation in the diabetic animals may be due to remarkable increase in the level of TBARs (lipid peroxidative marker) in the liver and kidney of diabetic rats. Moreover, drastic reduction of in vivo antioxidant enzymes level in various tissues was reported in diabetic condition (Hussein et al., 2014).

The observed oxidative stress - in this study- may deteriorate the synthesis and secretion of insulin which can be detected through the observed decrease in level of plasma insulin C-peptide after administration of STZ in group 5 (Table 2). That decrease in C-peptide level denotes a low insulin secretion which causes the attained hyperglycemia in the same group (Table 2). That hyperglycemia and consequently diabetes mellitus is not only caused by decreasing of insulin secretion but also through the observed inhibition in expression of GLUT4 protein (Table 2) in group 5 which results in retardation of myocardium uptaking of glucose.

Studies of Tomlinson et al., (1992) suggested free radical involvement in pancreatic cell destruction. GLUT4 is the most abundant glucose transporter isoform (Battell et al., 1998 and Toyoda et al., 2010) and primarily contributes to insulin stimulated glucose uptake in cardiomyocyte (Kraegen et al., 1994 and Belek et al., 2002). In three days, intravenous injection of $60 \mathrm{mg} / \mathrm{kg}$ of Streptozotocin made pancreas swell and caused decreases nicotinamide-adenine dinucleotide (NAD) in pancreas islet beta cells and degeneration 
in Langerhans islet beta cells which probably intermediates induction of diabetes, where serum insulin and C-peptide decreased and consequently serum glucose increased (Norouzian, et al, 2007). A specific decrease in the GLUT4 glucose transporter protein was observed in red (2-fold) muscle and cardiac muscle that was normalized by insulin therapy. In addition, GLUT4 mRNA was found to decrease in red muscle (2-fold). The effect of STZ-induced diabetes was time-dependent with maximal inhibition of insulin-stimulated glucose transport activity at $24 \mathrm{~h}$ in both red and white skeletal muscle and half-maximal inhibition at approximately $8 \mathrm{~h}$. In contrast, GLUT4 protein in red and white muscle remained unchanged until 4 and 7 days following STZ treatment, respectively. These data demonstrate that red skeletal muscle displays a more rapid hormonal/metabolicdependent regulation of GLUT4 glucose transporter protein and mRNA expression than white skeletal muscle.( Richardson, et al, 1991)

In the present study, increase in serum total cholesterol, triacylglycerol and TG and LDL-C levels as well as the reduction of HDL-C level were observed in STZ-induced diabetic rats (Tables 3 and 4).

Those results are confirmed by the previous finding of de Almeida, et al, (2012) who stated that STZuntreated diabetic rats were characterized by a significant elevation in the levels of total cholesterol, LDL cholesterol, VLDL cholesterol and triacylglycerols, as well as significant $(p<0.05)$ decreased levels of serum HDL cholesterol compared with the normal animals.

The hypertriglyceridaemia and VLDL in diabetes may be attined through an increase in the activity of hormone-sensitive lipase, which catalyses the mobilization of fatty acids from triacyglycerols stored in adipocytes to the liver triacylglycerols are resynthesized and secreted in VLDL. (Cullen et al. 1999; Reynisdottir et al. 1997). Also Kondo et al. (2007) recorded an inhibition in activity of the lipoprotein lipase enzyme which hydrolyses the triacylglycerols in VLDL and chylomicrons in cases of diabetes.

In this study, administration of trace elements $\left(\mathrm{Cr}^{+2}, \mathrm{Se}^{+2}\right.$ and $\left.\mathrm{Zn}^{+2}\right)$ to normal rats (groups: 2, 3 and4) did not cause any undesirable influence but produced some improvement higher than normal rats (group 1). This improvement was shown in tables (1) especially decrease of MAD level and increase GSH level $\left(\mathrm{Cr}^{+2}\right.$ and $\left.\mathrm{Zn}^{+2}\right)$ as well as activation of SOD activity. Also these trace elements ( Table 2) not only did not change plasma glucose and serum C-peptide significantly than normal group but increased expression of cardiac GLUT4 protein. Concerning lipid profile (Tables 3 and 4) showed that these trace element did not cause significant change than normal rats with observation that $\mathrm{Cr}^{+2}$ decreased total cholesterol, triacylglycerol and LDL levels than control group.
Adminstration glibenclamide (group 6) prevented the oxidative effect of STZ where MDA and SGH levels were lower than STZ-diabetic group and stilled within normal range, while SOD activity was higher than control group (Table 1). As glibenclamide prevented the oxidative effect of STZ, it interfered with bad effect of STZ on insulin and kept level of C-peptide within the normal range causing slight hyperglycaemia which was significantly lower than diabetic group. On the other hand, glibenclamide failed in prevention of dangerous effect of STZ upon GLUT4 expression where it increased slightly than diabetic rats and stilled lower than normal group (Table 2). Also glibenclamide interfered with the sever pronounced effect of STZ on lipid profile but caused mild significant increase of total cholesterol, triacylglycerol and LDL levels and decrease of HDL level than control group.

Glibenclamide is often used as an insulin stimulant and also used as a standard antidiabetic drug in STZ- induced moderate diabetes to compare the antidiabetic properties of a variety of hypoglycemic compounds (Andrade-Cetto et al., 2000).

Sulfonylurea antidiabetic agents such as glibenclamide promotes insulin secretion through inhibition of ATP-sensitive K+ (KATP) channels in the pancreatic cells (Obata and Yamanaka ,1998)

Glibenclamide possess direct mechanism to enhance the levels of SOD, CAT, glutathione-stransferase (GST) besides reducing the LPO in the STZ diabetic animals. (Altan ,et al, 1997; Bukan, et al, 2004 and Elmalí, et al, 2005)

The present results revealed that treatment of STZdiabetic rats with trace elements $\left(\mathrm{Cr}^{+2}, \mathrm{Se}^{+2}\right.$ and $\mathrm{Zn}^{+2}$ ) strengthened the endogenous antioxidant defenses (GSH and SOD) and prevented the oxidative stress through keeping the optimal oxidative balance by neutralizing produced ROS (Table 1). The administered three trace elements ( $\mathrm{Cr}^{+2}, \mathrm{Se}^{+2}$ and $\mathrm{Zn}^{+2}$ ) exhibited an antioxidative role as glibenclamide. These traces elements especially chromium prevented lipid hydroperoxide and kept GSH level and SOD activity within its normal range. As that trace elements stopped the oxidative effect of STZ, they protected the pancreas and its $\beta$-cells against degenerative effect of STZ . Therefore, insulin C-peptide level - and consequently insulin- in groups 7, 8 and 9 stilled within its normal range after 8 weeks. As a result of that plasma glucose level in these groups was slightly lower that of glibenclamide group but remained higher - to some extent- than normal group due to STZ injection. As glibenclamide failed in protection of GLUT4 expression, these three trace elements especially selenium not only prevented the GLUT4 expression inhibitory effect of STZ but also activated cardiac GLUT4 expression higher than normal rats after 8 weeks (Table 2). 
Administration of $\mathrm{Cr}^{+2}, \mathrm{Se}^{+2}$ and $\mathrm{Zn}^{+2}$ with $\mathrm{STZ}$ prevented the hyperlipidimic effect of STZ where the obtained data in tables 3 and 4 showed that the concentration of lipogram fractions in groups 7,8 and 9 are within the range of glibenclamide and normal groups. Zinc showed the most ameliorating effect influence on lipid profile.

These trace elements through keeping the circulating normal insulin level- as plasma Cpeptide concentration remained within normal range- interfered with lipolytic complications of SZT-induced diabetes. It is interesting to note that trace elements $\left(\mathrm{Se}^{+2}, \mathrm{Cr}^{+2}\right.$ and $\left.\mathrm{Zn}^{+2}\right)$ did not only lower the TC, TG and LDL levels, but also enhanced HDL-C of the diabetic rats afte 8 weeks of treatment.

Sahin et al., (2007) stated that trace elements; especially $\mathrm{Cr}^{+2}$ works with insulin to regulate glucose and also lowered free fatty acid levels by $24 \%$, blood urea by $33 \%$ and creatinine level by $25 \%$ and reduced the severity of glomerular sclerosis which was confirmed by normal renal tubular appearance in a rat model of type 2 diabetes mellitus group treated with chromium. That obtained results may be attributed to the maintenance influence of chromium for C-peptide level and insulin efficiency, which then keeps the blood glucose level. These nutritional supplements permit the transmission of glucose to muscle cells instead of fat cells (Hallmark et al., 1996).

Our data agree with Tobia et al (1998) who found that administration of zinc to streptozotocininduced diabetic rats was able to restore normoglycemia by enhancing glucose oxidation and stimulating glucose uptake by tissues. Zinc similarly exerts insulin-suppressive action by attenuating the hypersecretion of insulin associated with the prediabetic pancreas, thus "rest-"beta cells and preserving their structure and function (Shisheva et al., 1994).

Trace elements through its antioxidant effect act as protective agents against free radical injury in heart and kidney and reduction of lipid peroxidation in many tissues (Al-Shamaony et al., 1994). The increase in HDL-cholesterol is a desirable feature and the reduction in TC, TG and LDL-cholesterol levels could be beneficial in preventing diabetic complications as well as improving lipid metabolism in diabetics (Ramachandran et al., 2011).

This would definitely reduce the incidence of coronary events being the major cause of morbidity and deaths in diabetes subjects (Sivajothi et al., 2008). HDL-C transports cholesterol from peripheral tissues to the liver, thereby reducing the amount stored in tissues and decreasing the likelihood of getting atherosclerotic plagues (Singh et al., 2007). The possible mechanism by which trace elements can exert lipid lowering activities may be explained by decreasing the cholesterol biosynthesis, particularly by decreasing the activity of hydroxyl-3-methylglutaryl-coenzyme A (HMG$\mathrm{CoA}$ ) reductase or by reducing the NADPH required for cholesterol synthesis and/or by stimulating glucose utilization (Kochhar et al., 2007).

Tian-Jiao et al., (2011), through their immunohistochemical analysis of GLUT4 in cardiac muscle, found that trace element $\mathrm{Se}^{+2}$ restored GLUT4 expression close to normal values, suggesting that trace elements alleviated the obstacle of signal transduction on the level of postreceptor in cardiac muscle of diabetic rats.

In conclusion, the present study demonstrated the antioxidant, antihyperglycemic and hyperlipidemic effects of trace elements $\left(\mathrm{Cr}^{+2}, \mathrm{Se}^{+2}\right.$ and $\left.\mathrm{Zn}^{+2}\right)$ in comparison with antidiabetic drug "glibenclamide". The present data revealed a protective antioxidative effect of trace elements $\left(\mathrm{Cr}^{+2}, \mathrm{Se}^{+2}\right.$ and $\left.\mathrm{Zn}^{+2}\right)$ against hyperoxidation and degenerative effect of STZ on pancreatic $\beta$-cells.. Therefore, these trace elements $\left(\mathrm{Cr}^{+2}, \mathrm{Se}^{+2}\right.$ and $\left.\mathrm{Zn}^{+2}\right)$ have vital role in keeping normal plasma insulin C-peptide (and insulin) and GLUT4 expression which facilitates cellular uptaking of glucose and consequently stop various diabetic complications. 
Scientific Journal of October 6 University

ISSN (Print): 2314-8640

ISSN (Electronic): 2356-8119

Published by October 6 University (C) All Rights Reserved

Available online at: http://sjou.journals.ekb.eg

Original Article

\begin{tabular}{|c|c|c|c|c|c|c|c|}
\hline \multirow{2}{*}{$\begin{array}{l}\text { Main } \\
\text { Groups }\end{array}$} & \multirow{2}{*}{ Groups } & \multicolumn{2}{|c|}{ Malonodialdehyde (MDA) } & \multicolumn{2}{|c|}{ Reduced Glutathione (GSH) } & \multicolumn{2}{|c|}{$\begin{array}{c}\text { Blood Superoxide Dismutase } \\
\text { (SOD) }\end{array}$} \\
\hline & & $4^{\text {st }}$ week & $8^{\text {th }}$ week & $4^{\text {st }}$ week & $8^{\text {th }}$ week & 4- week & $8^{\text {th }}$ week \\
\hline \multirow{4}{*}{$\begin{array}{c}\text { I- } \\
\text { Main } \\
\text { Health } \\
\text { Group }\end{array}$} & 1)-Ve Control & $2.44 \underset{\mathrm{cdA}}{ \pm 0.09}$ & $2.51 \pm \underset{\mathrm{cdA}}{ \pm 0.05}$ & $52.85 \pm 4.46^{\mathrm{bA}}$ & $\underset{b c A}{51.59 \pm 3.73}$ & $\underset{\mathrm{cA}}{223.65} \pm 8.23$ & $\underset{\mathrm{dB}}{213.45 \pm 6.82}$ \\
\hline & 2)- $\mathrm{CrCl}_{3}$ & $1.89 \pm 0.10^{\mathrm{eA}}$ & $\underset{\substack{2.01 \pm\\
}}{2.01 \pm 07}$ & $57.96 \pm 1.34^{\mathrm{aA}}$ & $59.86 \pm 2.40^{\mathrm{aA}}$ & $\underset{\mathrm{aA}}{248.00 \pm 6.11}$ & $\underset{\mathrm{aA}}{243.65 \pm 5.47}$ \\
\hline & 3)- $\mathrm{Na}_{2} \mathrm{Se}$ & $\underset{\text { deA } \pm}{2.19 \pm 0.20}$ & $\begin{array}{c}2.14 \pm 0.07 \\
\operatorname{deA} \pm\end{array}$ & $44.18 \pm 4.85^{\mathrm{dA}}$ & $46.50 \pm 4.99^{\mathrm{dA}}$ & $\underset{\text { deA }}{217.26 \pm 3.95}$ & $\underset{\mathrm{cA}}{221.33 \pm 4.11}$ \\
\hline & 4)- $\mathrm{ZnSO}_{4}$ & $\underset{\substack{\text { deA } \pm 2.05 \pm 0.14}}{2}$ & $2.10 \pm \underset{\mathrm{eA}}{ \pm 0.04}$ & $47.96 \pm 3.15^{\mathrm{cdB}}$ & $\underset{\mathrm{abA} \pm}{55.59 \pm 3.08}$ & $\underset{b A}{237.33 \pm 3.84}$ & $\underset{b A}{233.65 \pm 5.62}$ \\
\hline \multirow{5}{*}{$\begin{array}{c}\text { II- } \\
\text { Main } \\
\text { Diabetic } \\
\text { Group }\end{array}$} & $\begin{array}{l}5)+\mathrm{Ve} \\
\text { Diabetic }\end{array}$ & $4.89 \pm 0.37^{\mathrm{aB}}$ & $5.47 \underset{\mathrm{aA}}{ \pm 0.04}$ & $18.55 \pm 2.67^{\mathrm{fA}}$ & $16.54 \pm 2.81^{\mathrm{fA}}$ & $\underset{\mathrm{gA}}{136.50 \pm 7.35}$ & $\underset{\mathrm{fB}}{119.72 \pm 5.63}$ \\
\hline & $\begin{array}{r}\text { 6)- } \\
\text { Glibenclamide }\end{array}$ & $2.80 \pm 0.10$ & $2.29 \pm \underset{\text { cde }}{0.13}$ & $37.56 \pm 2.39^{\mathrm{eB}}$ & $\underset{\text { cdA }}{49.52 \pm 2.58}$ & $\underset{\mathrm{fB}}{205.75 \pm 6.51}$ & $\underset{b A}{230.09} \pm 4.88$ \\
\hline & 7)- $\mathrm{CrCl}_{3}$ & $2.74 \pm 0.30^{\mathrm{bA}}$ & $2.22 \pm 0.04^{\mathrm{cB}}$ & $45.71 \pm 3.44^{\mathrm{bcB}}$ & $\underset{b c A}{51.16 \pm} 3.26$ & $\underset{\mathrm{eB}}{194.88 \pm 6.30}$ & $\begin{array}{c}222.24 \pm \\
5.95^{\mathrm{cA}} \\
\end{array}$ \\
\hline & 8)- $\mathrm{Na}_{2} \mathrm{Se}$ & $2.22 \pm 0.25^{\mathrm{bA}}$ & $2.94 \pm 0.17^{\mathrm{bB}}$ & $43.63 \pm 3.11^{\mathrm{efB}}$ & $47.37 \pm 2.63^{\mathrm{dA}}$ & $\underset{\mathrm{gB}}{159.26 \pm 5.04}$ & $\begin{array}{c}200.80 \pm \\
3.04^{\mathrm{eA}} \\
\end{array}$ \\
\hline & 9)- $\mathrm{ZnSO}_{4}$ & $2.99 \pm 0.58^{\mathrm{cA}}$ & $\begin{array}{r}2.63 \pm \\
0.11^{\mathrm{bcA}} \\
\end{array}$ & $50.40 \pm 2.35^{\mathrm{deB}}$ & $45.80 \pm 2.75^{\mathrm{cA}}$ & $179.51 \pm 4.82^{\mathrm{fB}}$ & $\begin{array}{c}214.92 \pm 3.18 \\
\mathrm{dA}\end{array}$ \\
\hline
\end{tabular}

Table (1): Effect of trace elements treatments on Serum Malonodialdehyde (MDA), Blood Reduced Glutathione (GSH) levels and Blood Superoxide Dismutase activity in diabetic and non diabetic rats at $4^{\text {th }}$ and $8^{\text {th }}$ weeks.

Data shown are mean \pm standard deviation of number of observations within each treatment.

Data followed by the same letter are not significantly different at $\mathrm{P} \leq 0.05$. Small letters are used for comparison between the means within the column. Capital letters are used to compare means within the row.

Table (2): Effect of trace elements on Plasma Glucose Level, Plasma C-Peptide and Heart Tissue GLUT4 of rats in different groups at $4^{\text {th }}$ and $8^{\text {th }}$ week

\begin{tabular}{|c|c|c|c|c|c|c|}
\hline \multirow{2}{*}{$\begin{array}{c}\text { Main } \\
\text { Groups }\end{array}$} & \multirow[t]{2}{*}{ Groups } & \multicolumn{2}{|c|}{ Plasma Glucose (mg/dl) } & \multicolumn{2}{|c|}{ Plasma Insulin C-peptide } & \multirow{2}{*}{$\begin{array}{c}\text { Heart Tissue } \\
\text { GLUT4 } \\
\text { 8 }^{\text {th }} \text { week } \\
\end{array}$} \\
\hline & & $4^{\text {st }}$ week & $8^{\text {th }}$ week & 4 $_{\text {st }}^{\text {week }}$ & $8^{\text {th }}$ week & \\
\hline \multirow{4}{*}{$\begin{array}{c}\text { I- } \\
\text { Main } \\
\text { Health } \\
\text { Group }\end{array}$} & 1)-Ve Control & $105.50 \pm 1.48^{\mathrm{eA}}$ & $98.50 \pm 3.84^{\mathrm{cA}}$ & $1.48 \pm 0.02^{\mathrm{eA}}$ & $1.48 \pm 0.01^{\mathrm{eB}}$ & $1.37 \pm 0.19^{\mathrm{f}}$ \\
\hline & 2)- $\mathrm{CrCl}_{3}$ & $107.00 \pm .2 .94^{\mathrm{dA} \pm}$ & $94.83 \pm 2.12^{\mathrm{cB}}$ & $1.53 \pm 0.01 \mathrm{dA} \pm$ & $1.41 \pm 0.01^{\mathrm{deA}}$ & $1.67 \pm 0.22^{\mathrm{e}}$ \\
\hline & 3)- $\mathrm{Na}_{2} \mathrm{Se}$ & $102.00 \pm 4.65^{\mathrm{cdA}}$ & $104.41 \pm 1.56^{\mathrm{cB}}$ & $1.44 \pm 0.01^{\mathrm{cdA}}$ & $1.34 \pm 0.008^{\mathrm{cdA}}$ & $1.51 \pm 0.23^{\text {ef }}$ \\
\hline & 4)- $\mathrm{ZnSO}_{4}$ & $96.66 \pm 3.11^{\mathrm{dA} \pm}$ & $103.00 \pm 1.15^{\mathrm{cB}}$ & $1.48 \pm 0.003^{\mathrm{dA}}$ & $1.37 \pm 0.008^{\text {cdeA }}$ & $1.47 \pm 0.04^{\mathrm{cd}}$ \\
\hline \multirow{5}{*}{$\begin{array}{c}\text { II- } \\
\text { Main } \\
\text { Diabetic } \\
\text { Group }\end{array}$} & 5) + Ve Diabetic & $365.50 \pm 7.66^{\mathrm{aA}}$ & $362.33 \pm 15.22^{\mathrm{aA}}$ & $0.53 \pm 0.006^{\mathrm{aA}}$ & $0.46 \pm 0.02^{\mathrm{aA}}$ & $0.73 \pm 0.21^{\mathrm{de}}$ \\
\hline & $\begin{array}{r}\text { 6)- } \\
\text { Glibenclamide }\end{array}$ & $155.00 \pm .6 .77^{\mathrm{bA} \pm}$ & $123.33 \pm 1.94^{\mathrm{bB} \pm}$ & $1.36 \pm 0.006^{\mathrm{cA}}$ & $1.45 \pm 0.01^{\mathrm{cB}}$ & $0.93 \pm 0.05^{\text {ef }}$ \\
\hline & 7)- $\mathrm{CrCl}_{3}$ & $188.83 \pm 38.59^{\mathrm{cA}}$ & $112.50 \pm 4.07^{\mathrm{bB}}$ & $1.21 \pm 0.05^{\mathrm{bB}}$ & $1.47 \pm 0.02^{\mathrm{aA}}$ & $1.43 \pm 0.42^{\mathrm{bc}}$ \\
\hline & 8)- $\mathrm{Na}_{2} \mathrm{Se}$ & $179.83 \pm 46.64^{\mathrm{cA}}$ & $118.16 \pm 5.53^{\mathrm{bcB}}$ & $1.09 \pm 0.02^{\mathrm{bB}}$ & $1.44 \pm 0.008^{\mathrm{abA}}$ & $2.07 \pm 0.21^{\mathrm{a}}$ \\
\hline & 9)- $\mathrm{ZnSO}_{4}$ & $198.33 \pm 28.72^{\mathrm{bA}}$ & $125.00 \pm 5.34^{\mathrm{bcB}}$ & $1.13 \pm 0.01^{\mathrm{bB}}$ & $1.45 \pm 0.009^{\mathrm{abcA}}$ & $1.67 \quad 0.25^{\mathrm{b}}$ \\
\hline
\end{tabular}

Data shown are mean \pm standard deviation of number of observations within each treatment.

Data followed by the same letter are not significantly different at $P \leq 0.05$. Small letters are used for comparison between the means within the column. Capital letters are used to compare means within the row.

\section{References}

- Abel ED, Peroni O, Kim JK, Kim YB, Boss O, Hadro E, Minnemann T, Shulman GI, and Kahn BB (2001). Adipose selective targeting of the GLUT4 gene impairs insulin action in muscle and liver. Nature 409, 729-733.

- Allain CC, Poon LS, Chan CS, Richmond W, and Fu PC. (1974). Enzymatic determination of total serum cholesterol. Clin Chem 20: 470 .

- Al-Shamaony L, Al-Khazraji SM and Twaiji HA. (1994). Hypoglycemic effect of Artemisia herba alba II. Effect of a valuable extract on some blood parameters in diabetic animals. $\mathbf{J}$ Ethnopharmacol; 43: 167.
- Altan N, Yiğit S, Elmali E, Malhatun E, Rota S and Kilic N.( 1997). Effect of the sulphonylurea glyburide on superoxide dismutase in streptozotocin-induced diabetic rat muscle. Gen Pharmacol.;28:795-6.

- Aly, HF and Mantawy, MM. (2012). Comparative effects of zinc, selenium and vitamin $\mathrm{E}$ or their combination on carbohydrate metabolizing enzymes and oxidative stress in streptozotocin induced-diabetic rats European Review for Medical and Pharmacological Science, 16: 66-78.

*Corresponding Author Address: Prof. Mohammed Abdalla Hussein: Department of Biochemistry, Faculty of Applied Medical Sciences, October 6 University, Egypt. E-mail: Prof.husseinma@o6u.edu.eg 
- Andallu B. and Varadacharyulu N. (2003). Antioxidant role of mulberry leaves in streptozotocin- diabetic rats. Clin Chim Acta; 338: 3-10.

- Andrade-Cetto A, Wiedenfeld H, Revilla Mac and Islay S. (2000). Hypoglycemic effect of Equisetum myriochaitum aerial parts on streptozotocin diabetic rats. J Ethnopharmacol; 72: 129137.

- Battell ML, Delgetty HLM and Mcneil JH. (1998). Sodium selenate corrects glucose tolerance and heart function in STZ diabetic rat. Mol Cell Biochem. 179: 27-34.

- Baynes JW. (1991). Role of oxidative stress in development of complications in diabetes. Diabetes; 40:405-411.

- Belek DD, Betuing S, Tuttle MJ, Graveleau C, Young ME, Pham M, Zhang D, Cooksey RC, Mcclain DA, Litwin SE, Taegtmeyer H, Severson D, Kahn CR and Abel ED. (2002). Insulin signaling coordinately regulates cardiac size, metabolism, and contractile protein isoform expression. J Clin Invest. 109: 629-639.

- Bonger A and Garcia-Webb P. (1984). C-Peptide Measurement: Methods and Clinical Utility. CRC Critical Reviews in Clinical Laboratory Sciences. 19:297-306

- Bukan N, Sancak B, Bilgihan A, Kosova F, Bugdayci G and Altan N. (2004). The effects of the sulphonylurea glyburide on glutathione peroxidase, superoxide dismutase and catalase activities in the heart tissue of streptozotocin induced diabetic rat. Methods Find Exp Clin Pharmacol.;26:579-22.

Chanarin I (1989). Textbook of laboratory haematology: An account of laboratory techniques. Churchill living stone.new York,pp.107

- Coskun O, Kanter M, Korkmaz A and Oter S. (2005). Quercetin, a flavonoi antioxidant, prevents and protects streptozotocin-induced oxidative stress and $\beta$-cell damage in rat pancreas. Pharmacol Res. 51: 117-23.

- Cullen P, Eckardstein A, Souris S, Schulte H. and Assmann G. (1999). Dyslipidaemia and cardiovascular risk in diabetes. Diabetes Obes. Metab. 1: 189-98.

- de Almeida, D. A.T, Braga, C. P. , Novelli, E. L. B. and Fernandes, A. A. H. (2012). Evaluation of lipid profile and oxidative stress in STZ-induced rats treated with antioxidant vitamin. Braz. arch. biol. technol. vol.55 no.4

- Dias AS, Porawski M, Alonso M, Morroni N, Collado PS and González-Gallego J. (2005). Quercetin Decreases Oxidative Stress, NF-B Activation, and iNOS Overexpression in Liver of Streptozotocin-Induced Diabetic Rats. J. Nutr.; 135: 2299-304.

- Elmalí E, Altan N and Bukan N. (2005). Effect of the sulphonylurea glibenclamide on liver and kidney antioxidant enzymes in streptozotocin-induced diabetic rats. Drugs RD. 5:203-8.

- Fossati P and Prencipe L. (1982) Serum Triglycerides Determined Colorimetrically with an Enzyme that Produces Hydrogen Peroxide. Clinical Chemistry, 28, 2077-2080.

- Friedwald WT, Levy RI and Fredrickson DS. (1972). Estimation of the concentration of LDL-C in plasma without use of the preparative ultracentrifuge. Clin Chem. 18:449-502.

- Garg MC, Ojha S, and Bansal D. (1996). Antioxidant Status of streptozotocin - diabetic rats. Indian J Exp Biol; 34: 264-271

- Hallmark MA, Reynolds TH, DeSouza CA, Dotson CO, Anderson RA and Rogers MA. (1996). Effects of chromium and resistive training on muscle strength and body composition. Med. Sci. Sports Exerc., 28: 139-144.

- Hussein AA, Hussein MA, Soha AH and Anwar K. (2014). Antidiabetic Activity of Viciafaba L. vicine and its Odeglycosylation product, divicinein STZ-induced diabetic rats. International Journal of Pharma Sciences. 2: 454-463

- Jacob, RA. (1995). The integrated antioxidant system. Nutr Res; 15: 755-762.

- Jain SK. and Kannan K. (2001). Chromium Chloride Inhibits Oxidative Stress and TNF- $\alpha$ Secretion Caused by Exposure to High Glucose in Cultured U937 Monocytes. Biochemical and Biophysical Research Communications. 289: 687-691.

- Ju JB, JiSK, Choi CW, Lee HK, Oh T and Kim C. (2008). Comparison between ethanolic and aqueous extracts from Chinese juniper berries for hypoglycaemic and hypolipidemic effects in alloxaninduced diabetic rats. J. Ethnopharmacol. 115:110-115.

- Kochhar A, Malkit N and Rajbir S. (2007). Effect of supplementation of traditional medicinal plants on serum lipid profile in non-insulin dependent diabetics. J. Hum. Ecol, 5: 13540 .

- Kondo HU, Kiyose C, Ohmori R, Saito H. Tagughi C, Kishimoto Y. (2007). Improves Lipoprotein Metabolism in Humans. J. Nutr. Sci. Vitaminol.; 53: 345-8.

- Kowluru RA, Engerman RL, Case GL, Kern TS. (2001). Retinal glutamate in diabetes and effect of antioxidants. Neurochem Int, 38: 385-390.

- Kraegen EW, Sowden JA, Halstead MB, Clark PW, Rodnick KJ, Chisholw DJ and James DE. (1994). Glucose transporters and in vivo glucose uptake in skeletal and cardiac muscle: fasting, insulin cells. Bioessays. 16: 753-759.

- Kunwar A. and Priyadarsini KI. (2011). Free radicals, oxidative stress and importance of antioxidants in human health. J Med Allied Sci, 1(2): 53-60.

- Levesque, $\quad$ R (2007). SPSS Programming and DatalManagement: A Guide for SPSS and SAS Users, Fourth Edition (2007), SPSS Inc., Chicago Ill.

- Liu H, Liu X, Lee J, Liu Y, Yang H, and Wang G (2008).Insulin therapy restores impaired function and expression of P-glycoprotein in blood-brain barrier of experimental diabetes. Biochem Pharmacol. 75(8):1649-1658.

- Livak J.K. and Schmittgen T.D (2001). Analysis of relative gene expression data using real time quantitative PCR and the 2$\{$ delta $\}\{$ delta $\}$ ct method. Methods. 25: 402-408.

- Lockitch G. Halstead AC. Albersheim S. Quigley G. Reston L. Jacobson B. (1988). Age and sex specific pediatric reference intervals and correlation for $\mathrm{Zn}$, copper, selenium, iron, vitamin $\mathrm{A}$ and $\mathrm{E}$ and related proteins in normal children. Clin Chem. 34(4): 1625-1628

- Majithiya JB. and Balaraman R. (2005). Time-Dependent Changes in Antioxidant Enzumes and Vascular Reactivity of Aorta in Streptozotocin-Induced Diabetic Rats Treated With Curcumin. J. Cardiovasc. Pharmacol.; 46: 697-705.

- Marklund S, and Marklund G. (1974). Involvement of the superoxide anion radical in the autoxidation of pyrogallol and a convenient assay for superoxide dismutase. Eur J Biochem. 16; 47(3):469-74

- Merzouk S, Hichami A, Sari A, Madani S, Merzouk H, Berrouiguet, YA, and Lenoir-Rousseaux (2004). Impaired Oxidant/Antioxidant Status and LDL-fatty acid composition are associated with increased susceptibility to peroxidation of LDL in diabetic patients. Gen. Physiol. Biophys.; 23: 387-99.

- Nemati S, Jafary SP, Nahrevanian H, Farahmand M. and Nahrevanian S. (2012). Immuno-biochemical alterations in Leishmania major infected balb/ c mice after immunization with killed Leishmania vaccine and BCG as adjuvant. Curr Res J Biol Sci, 4(6): 706-712.

- NorouzianM. R., Mehrabi Sh., Jamshidi A., Farhangi A., Allah Verdi S. M. A., Mofidian B. and Lame Rad (2007). Induction of diabetes by Streptozotocin in rats. Indian Journal of Clinical Biochemistry, 22, Issue 2, pp 60-64

- Obata T and Yamanaka Y. (1998). Glibenclamide, an antagonist of ATP-sensitive $\mathrm{K}+$ channels, blocks free radical generation in the rat myocardium. Neurosci Lett.;257:57-9.

- O'Connell, BS. (2001). Select vitamins and minerals in the management of diabetes. Diabetes Spectrum.14:133-148.

- Olson SE. and Seidel GE. (2000) . Culture of in vitroproduced bovine embryos with vitamin $\mathrm{E}$ improves development in vitro and after transfer to recipients. Biol Reprod; 62(2): 248-52.

- Qiao W, Peng Z, Wang Z, Wei J, and Zhou A. (2009). BioTrace Elem Res.,131(2):133-42.

- Rajasekaran S, Sivagnanam K, Ravi K, and Subramanian S (2004). Hypoglycemic effect of Aloe vera gel on streptozotocin induced diabetic rats. J Med Food; 7: 61-68.

- Ramachandran S, Rajasekaran A and Kumar K. (2011). Antidiabetic, antihyperlipidemic and antioxidant potential of methanol extract of Tectonagrandis flowers in streptozotocin induced diabetic rats. Asian Pac J Trop Med, 4: 624- 631 
- Ramesh B and Pugalendi KV. (2005). Impact of umbelliferone on erythrocyte redox status in STZ-diabetic rats. Yale J. Biol. Med. 78: 131-8.

- Ravi K, Ramachandran B. and Subramanian S. (2004). Protective effect of Eugenia jambolana seed kernel on tissue antioxidant in streptozotocin-induced diabetic rats. Biol. Pharm.; 27: 1212-7.

- Reynisdottir S, Angelin B, Langin D, Lithell H, Eriksson M, Holm C. (1997). Adipose tissue lipoprotein lipase and hormone sensitive lipase. Ateriosclerosis, Thrombosis Vasc. Biol. 17: 2287-92.

- Richardson J M, Balon T W, Treadway J L and Pessin J E (1991). Differential regulation of glucose transporter activity and expression in red and white skeletal muscle. The Journal of Biological Chemistry, 266 : 12690-12694.

- Sahin K, Onderci M, Tuzcu M, Ustundag B, Cikim G, Ozercan I, Sriramoju I, Juturu $\mathbf{V}$ and Komorowski J (2007). Effect of chromium on carbohydrate and lipid metabolism in a rat model of type 2 diabetes mellitus: the fatfed, streptozotocin treated rat. Metabolism, 56(9): 1233-40.

- Sanders RA, Rausche FM and Watkins JB.( 2001). Effects of quercetin on antioxidant defense in streptozotocininduced diabetic rats. J Biochem Mol Toxicol.; 15: 143-9.

- Shisheva A, Gefel D and Shechter Y. (1994). Insulin-like effects of zinc ion in vitro and in vivo. Diabetes. 41; 982-988.

- Singh SK, Achyut NK, Gupta RK, Dolly J and Watal G. (2007). Assessment of antidiabetic potential of Cynodondactyl on extract in STZ-diabetic rats. J. Ethnopharmacol. 114:174179.

- Sivajothi V, Akalanka D, Balasundaram J and Balasubramanian R. (2008). Antihyperglycemica ntihyperlipidemic and antioxidant effect of Phyllanthusrheediion streptozotocin induced diabetic rats. Iran J. Pharm. Res, 1:53-59. - Tian-Jiao Xu, Liu Y and Yuan B. (2011). Effect of insulin in combination with selenium on IRS/PI3K-mediated GLUT4 expression in cardiac muscle of diabetic rats. European Review for Medical and Pharmacological Sciences. 15: 1452-1460.

- Taniguchi N. (1992) . Clinical significance of superoxide dismutases: changes in aging, diabetes, ischemia and cancer. Adv. Clin. Chem.; 29: 1-59.

- Tobia MH, Zdanowicz M, Wingertzahn MA, Atkinson BM, Slonim AE, Raul A and Wapnir RA. (1998). The role of dietary zinc in modifying the onset and severity of spontaneous diabetes in the BB Wistar rat. Mol Gen Metab. 63: 205-213.

- Tomlinson KC, Gardiner SM, Hebden RA and Bennett T. (1992). Functional consequences of streptozotocin-induced diabetes mellitus, with particular reference to the cardiovascular system. Pharmacol Rev; 44: 103-110.
- Toyoda T, An D, Witczak CA, Koh HJ, Hirshman MF, Fujii N and Goodyear LJ. (2010). Myo1c regulates glucose uptake in mouse skeletal muscle. J Biol Chem, 12: 1-17.

- Trinder P. (1969) Glucose determination method (enzymatic colorimetric method). Ann Clin Biochem; 6: 24-

- Trivedi N.A., Majumder B., Bhatt J.D and Hemavathi K.G. (2004). Effects of Shilajit on blood glucose and lipid profiles in alloxan- induced diabetic rats. Indian J Pharmacol.; 36: 373-376

- Uchiyama M, and Mihara M. (1978). Determination of malondialdehyde precursor in tissues by thiobarbituric acid test. Anal. Biochem., 86: 271 - 278

- Warnick GR, Nguyen T and Alberts AA. (1985). Comparison of improved precipitation methods for quantification of high-density lipoprotein cholesterol. Clin Chem. 31:217.

- Yanardag R, Peksel A, Yesilyaprak B, Doger MM. and Atac AI. (2005). Effects of a combination of niacin and chromium (III)-chloride on the skin and lungs of hyperlipemic rats. 103 (3): 249-260.

- Yilmaz HR, Uz E, Yucel N, Altuntas I and Ozcelik N. (2004). Protective effect of caffeic acid phenethyl ester (CAPE) on lipid peroxidation and antioxidant enzymes in diabetic rat liver. J Biochem Mol Toxicol.; 18: 234-8.

- Zine K, EL-Hadjla D, and Naima L (2007). The beneficial effect of vitamin E supplementation on zinc status, carbohydrate metabolism, transaminases and alkaline phosphatase activities in alloxan-diabetic rats fed on zinc deficiency diet. Int J Diabetes \& Metabolism, 15: 46-50. 